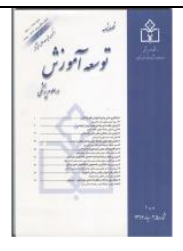



http://zums.ac.ir/edujournal/

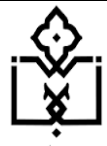

$\therefore$ (⿻)

.

مقاله يزوهشى اصيل

بررسى نگرش و عملكرد يرستاران شر كت كننده در دورههاى آموزشى ضمن خدمت نسبت

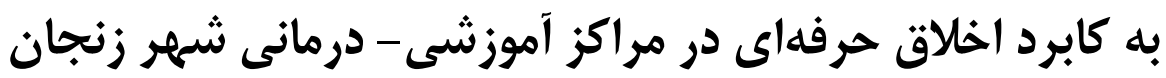

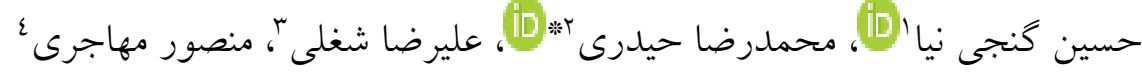

دريافت: ع ع

جكيده

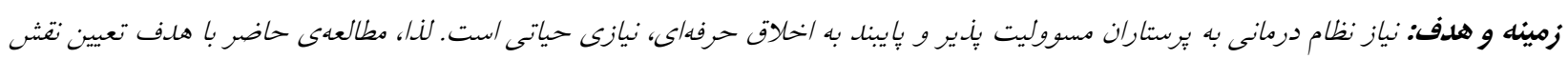



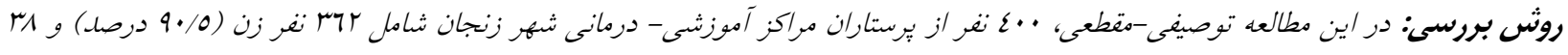

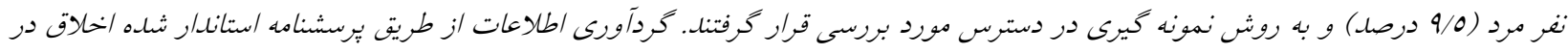

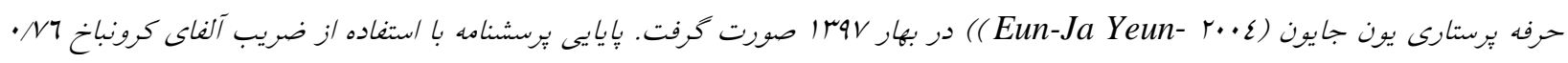

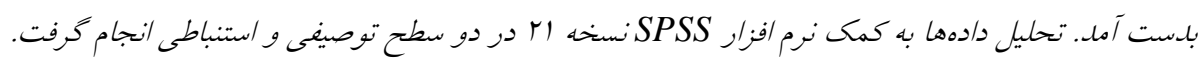

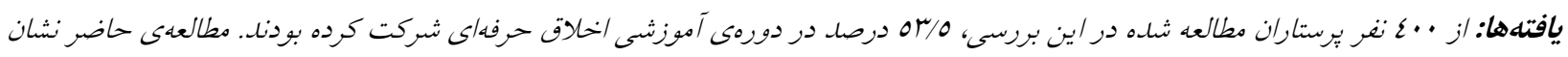

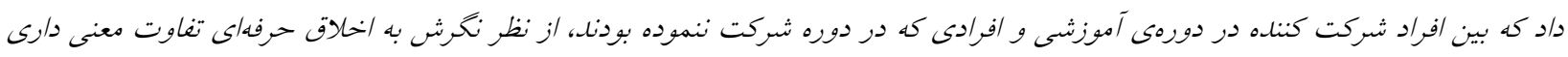

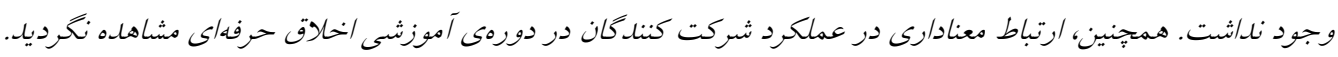

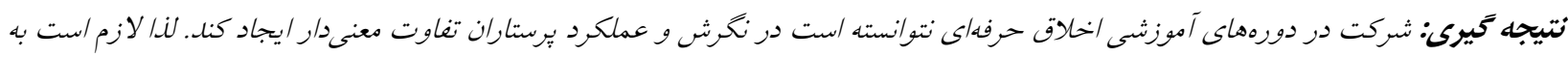

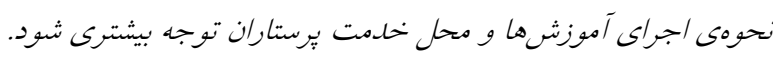

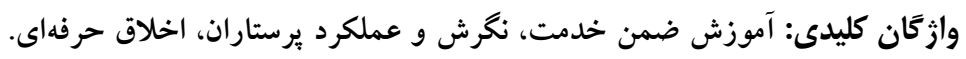

اين مقاله بدين صورت ارجاع داده شود:

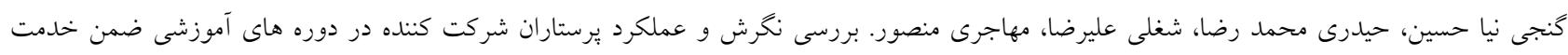

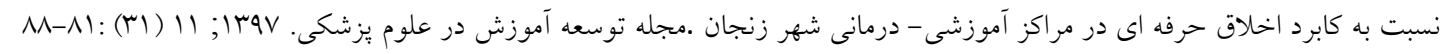

$$
\begin{aligned}
& \text { 1- كروه مديريت و حسابدارى، دانشخاه آزاد اسلامى، رشت، ايران. } \\
& \text { ז-. كروه مديريت رفتار سازمانى، دانشخاه آزاد اسلامى، رشت، ايران. }
\end{aligned}
$$

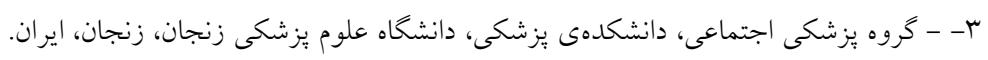

$$
\begin{aligned}
& \text { ع- كارشناس ارشد يُزوهشخرى، دانشكاه علوم يزشكى زنجان، زنجان، ايران. }
\end{aligned}
$$

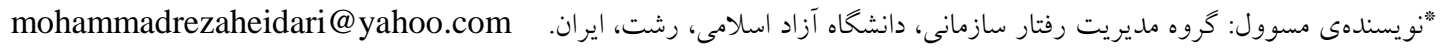




\title{
Evaluation of Attitude and Performance of Nurses Attending In-service Training courses Regarding the Use of Professional Ethics in Educational Healthcare Centers of Zanjan, Iran
}

\author{
Hossein Gangineia $^{1}(\mathrm{D})$, Mohammadreza Heidar ${ }^{2 *(D)}$, Alireza Shoghli ${ }^{3}$, Mansoor Mohajer ${ }^{2}$ \\ ${ }^{1}$ Faculty of Management and Accounting, Islamic Azad University, Rasht, Iran. \\ ${ }^{2}$ Zanjan University of Medical Sciences ,Zanjan,Iran. \\ ${ }^{3}$ Department of Social Medicine, Zanjan University of Medical Sciences, Zanjan,Iran.
}

\section{Article Info}

Article Type:

Original Article

Article history:

Received 14 JUn 2018

Accepted 01 Dec 2018

Published 20 Dec 2018

\section{Keywords:}

In-service Education

Attitude and Performance of Nurses

Professional Ethics

\begin{abstract}
Background and Objective: The healthcare system seeks responsible nurses, who are committed to professional ethics, which is a vital requirement in this area. Therefore, this study aimed to determine the role of in-service training courses in the attitude of nurses toward professional ethics and their performance in three educational healthcare centers of Zanjan, Iran.

Materials and Methods: This descriptive and cross-sectional research was performed on 400 nurses in educational healthcare centers of Zanjan, including 362 female (90.5\%) and 38 male (99.5\%) individuals, who were selected via convenience sampling. Data collection was carried out using the standardized questionnaire of ethics in nursing profession by Eun-Ja Yeun (2004) in the spring of 2018. Reliability of the mentioned survey was estimated at the Cronbach's alpha of 0.76 . Data analysis was performed in SPSS version 21 at two descriptive and inferential levels.

Results: From 400 nurses assessed, 53.5\% attended the educational courses on professional ethics. According to our findings, no significant difference was observed between the subjects who attended the courses and those who did not participate in the educational classes in terms of attitude toward professional ethics. Moreover, no significant association was found in the performance of participants who attended the mentioned classes before and after the intervention. Conclusion: According to the results of the study, participation in educational courses on professional ethics failed to make a significant difference in the attitude and performance of nurses. Therefore, more attention must be paid to the implementation of educations and place of work of nurses.
\end{abstract}

"Corresponding author: Mohammadreza Heidar, Email: mohammadrezaheidari@yahoo.com 
مىشود. جنين تغييراتى منجر به ارائهى ديدكاههاى جديد و

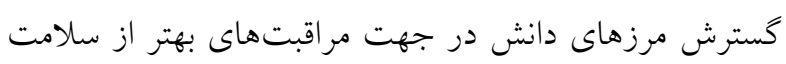
انسان مىشود كه حرفه يرستارى نيز از اين منظر مستثنى

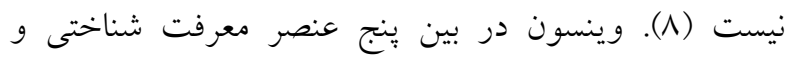

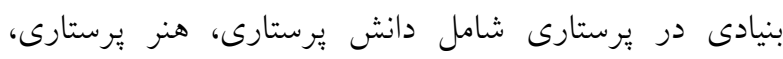



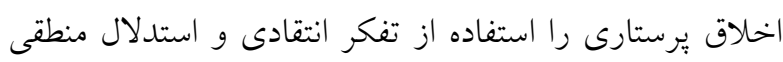
شرايط اخلاقى و فلسفى تعريف كرده است (9). رعايت معيارهاى اخلاق در عملكرد برستارى از ساير موارد مراقبت



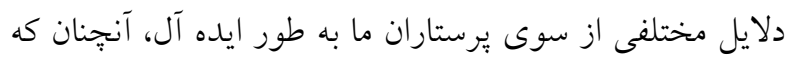

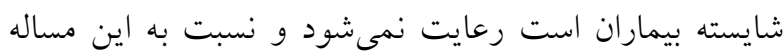
سهل انخارى شده است. نتايج مطالعهى مقايسهاى در مورد

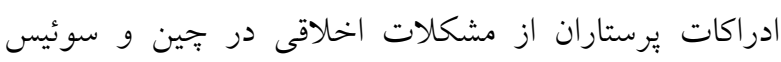
نشان مىدهد كه در بعضى حوزههاى اخلاقى مبتنى بر فرهنى و اعتقادات، تفاوتهايى وجود دارد، ضمن اين كه يرستاران جينى در حين و بعد از كار، اغلب عصبى، ناراضى و غمخين

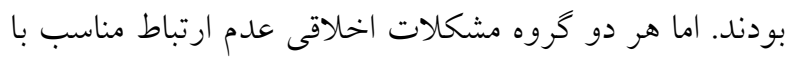

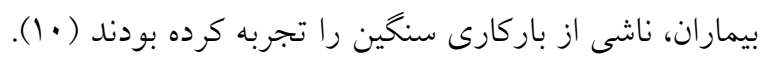

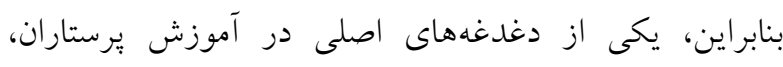
نحوهى افزايش توانايى آنان در موضوعات اخلاق حرفهاى

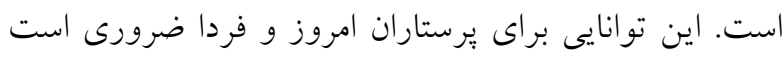
(1). لازمههاى صحيح نقشهاى برستارى برى علاوه بر بر انجام

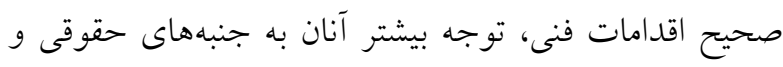

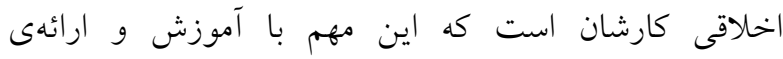
راهبردهاى مناسب براى عملكرد اخلاقى يرستاران قابل

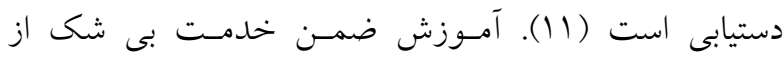
مهمترين و مؤثرترين عوامل بهبود امور سازمان و افزايش كارايى است (Y) (I). جيبرو و تكلب (Chiaburu \&Tekleab) آموزش ضمن خدمت را طراحى مداخلهى برنامه ريزى شده

\section{مقدمه}

اخلاق عبارت است از صفات نفسانى راسخ و بِايدارى كه

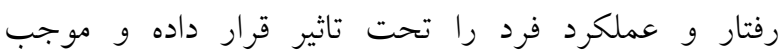
مىشوند افعالى متناسب با آن صفات به سهولت و بدون بحون نياز

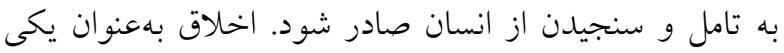

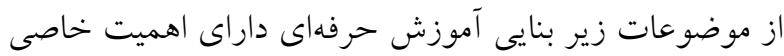

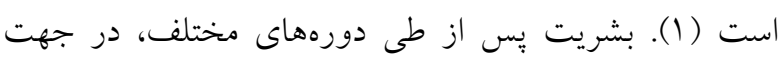
داشتن رويكردى عقلانى و اخلاقى در تأمين نيازهاى مادى و معنوى خود يِش مىرود. از اين جهت مىتوان اخلاق را

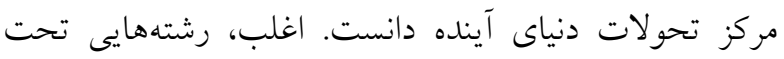

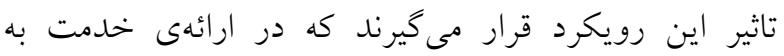

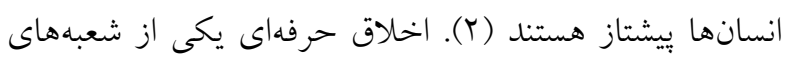
جديد اخلاق است كه مىكوشد تا به خالشها و مسائل

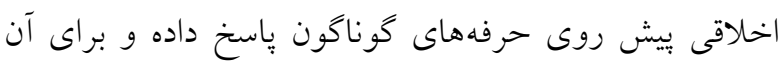

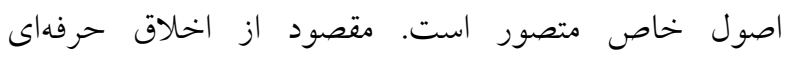
مجموعه قواعدى است كه لازم است افراد داوطلبانه و بر اساس نداى وجدان و فطرت خويش، در انجام كار حرفهاى رعايت كنند، بدون آنكه الزام خارجى داشته باشند يا در صورت تخلف، به مجازاتهاى قانونى دجار شوند (r).

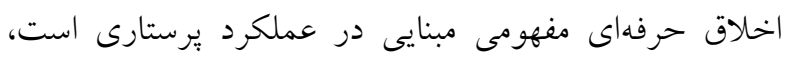

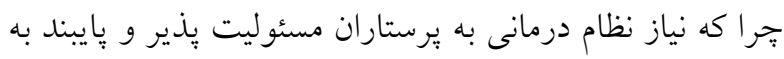
اخلاق حرفهاى، نيازى حياتى است (ع). هرجند رئل رعايت اخلاق در همه مشاغل با اهميت است اما در حرفه يرستارى

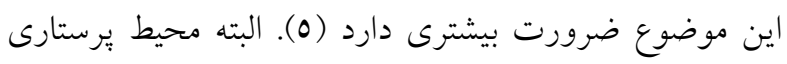

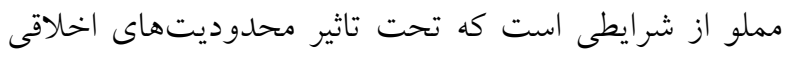
و قانونى قرار دارد (7). يرستاران هنگام انجام خدمات مراقبت از بيمار با مشكلات اخلاقى منحصر بفردى مواجه مىشوند

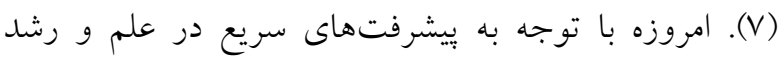

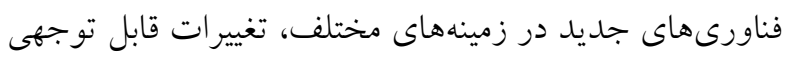
در همه حرفهها از جمله حرفههاى بهداشتى و درمانى ديده 


\section{روش بررسى}

در اين مطالعهى توصيفى - مقطعى، جامعهى آمارى كليهى

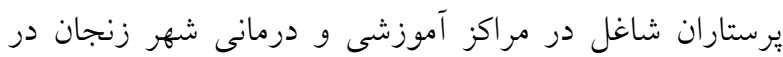

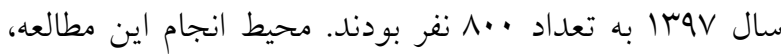


شهيد بهشتى شهر زنجان و روش جمع آورى نمونها، نمونه

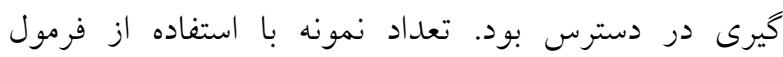
كوكران عیب نفر محاسبه شد كه در عمل و براى افزايش


تصويب طرح در كميتهى اخلاق در بزّوهش دانشخاه علوم


(IRZUMS.REC.1397.017) رضايت آكاهانه در مورد اجراى طرح كرفته شد و به ايشان

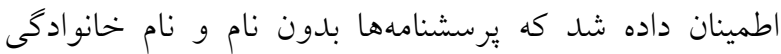
خواهد بود و اطلاعات دموكرافيك آنان به صورت محرمانه

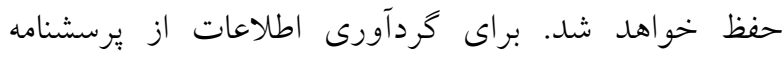
استاندارد شده اخلاق در حرفهى يرستارى يون جايون (Eun-Ja Yeun)

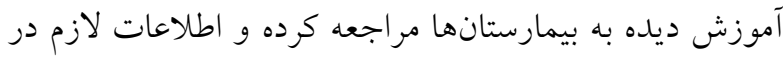

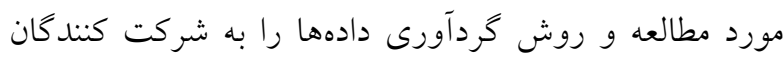
ارائه دادند. مدت زمان r هفتهاى براى ير كردن برسشنامه به شركت كنندكان داده شده و سبِ :ِرسشنامهاى تكميل شده توسط خود يرسشخران جمع آورى شد. دادهها به كمك نرم

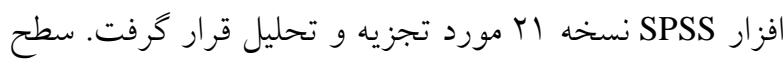

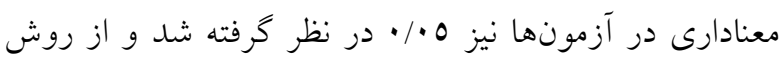

$$
\text { مقايسه ميانخينها استفاده خرديد. }
$$

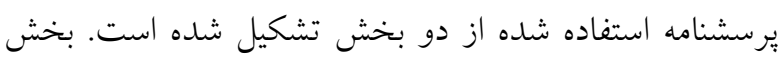

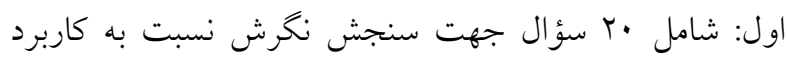
اخلاق و بخش دوم: شامل 0 سؤال جهت سنجش عملكرد نسبت به كاربرد اخلاق مىباشد. نمرهى دهى يرسشنامه بر بر برك اساس مقياس 0 گزينهاى ليكرت از كاملاً موافقم (0) تا كاملاً
براى افزايش عملكرد شغلى افراد مىدانند (rا) . يك برنامهى آموزشى ضمن خدمت كه بخوبى برنامه ريزى شده باشد، بايد

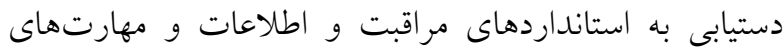

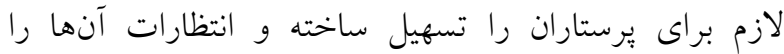

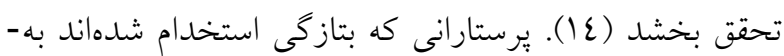

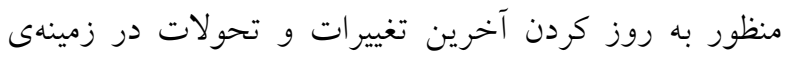

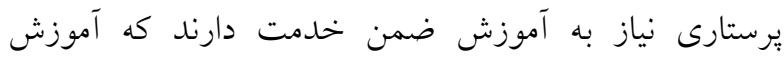
اخلاق در برستارى نيز بهواسطه اهميت فزايندهاى كه در سال-

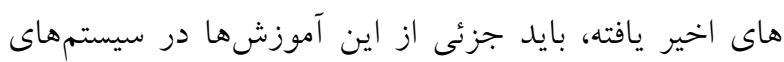

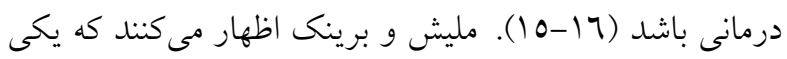
از اهداف آموزشهاى ضمن خدمت، ضمانت كردن استقلال، تفكر و صلاحيت يرستاران مطلع به كار داراى گواهى مىباشد

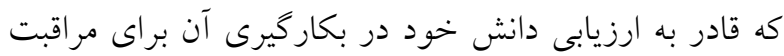

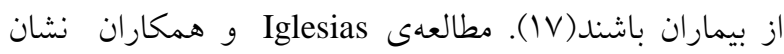


اخلاقى و حقوقى ايجاد كند، اما به نظر مىرسيد در اين زمينه

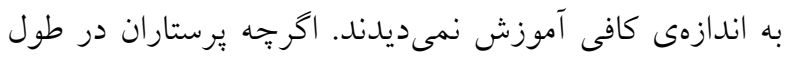

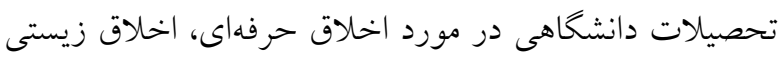
و قوانين برستارى آموزش ميديدند ولى ولى به آموزشهاى

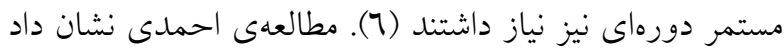
كه اخلاق حرفهاى در سازمانهاى مورد مطالعه از وضعيت مناسبى برخوردار نيست و عواملى در سه سطح فرا سازمانى

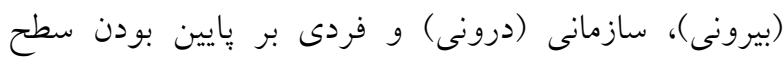
اخلاق حرفهاى كاركنان در سازمانهاى مورد بررسى مؤثر

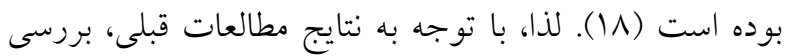
ميزان تاثير آموزشهـاى ضمـن خدمــت و نحسوهى ارائهى آنها در نخرش برستـاران به اخلاق حرفهاى از اهميت

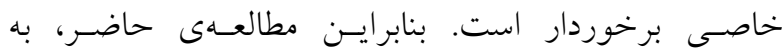

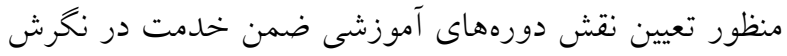
و عملكرد يُرستاران به اخلاق حرفهاى طراحى و به اجرا درآمد. 
ارائهى خدمت و احترام به بيمار بوده است. يرسشنامه مورد

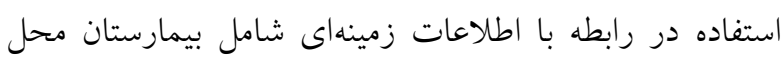
خدمت، سابقهى كار، نوع شيفت، سن، جنسيت، سطح تحصيلات، بخش فعاليت در بيمارستان، سمت (يرستار، سريرستار، سويروايزر و مترون) مىباشد.

يافتهها

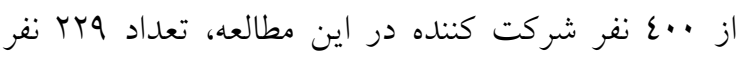

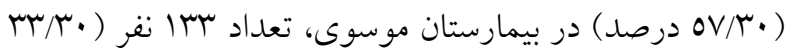
درصد) در بيمارستان ولى عصر و تعداد رب نفر (ع/q درصد)

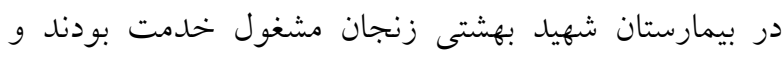
تعداد عاب نفر (م/O/O درصد) سابقه شركت در دورهى

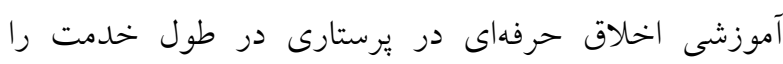

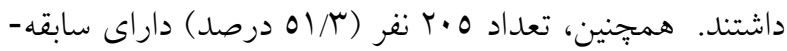
ى كار كمتر از •ا سال، تعداد عال انفر (اع درصد)، داراى

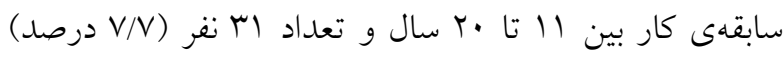
نيز داراى سابقهى كار بالاتر از • · سال بودند.

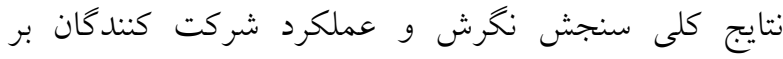
اساس شركت در دورههاى آموزشى ضمن خدمت نسبت به به

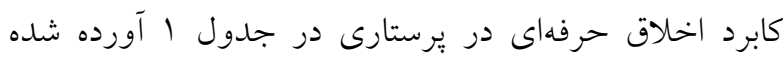
است. نتايج مقايسهى نخرش و عملكرد يرستاران به كاربرد اخلاق حرفهاى بر حسب برخى متغيرهاى زمينهاى در جدول r نشان داده شده است.
مخالفم (1) بود . بيشترين نمره 1roا و كمترين نمره حاصل از اين ابزار 0 م مىباشد.

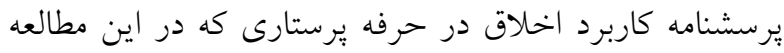

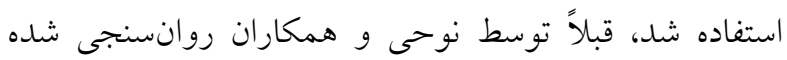

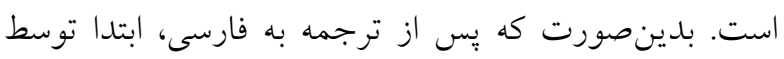

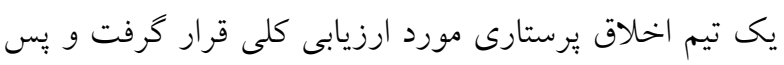
از تأييد كويههاى آن توسط تيم مورد نظر، توسط يكى فرد برد

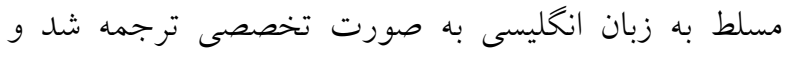

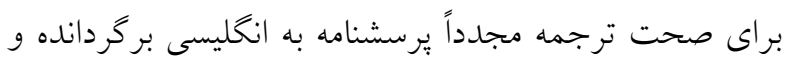

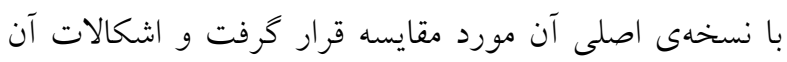

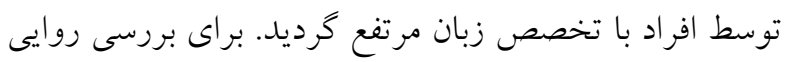

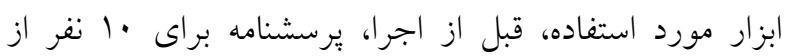



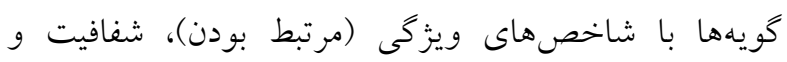

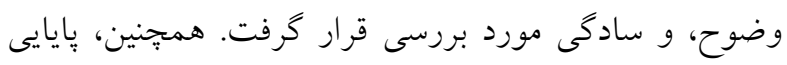

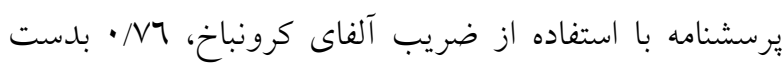

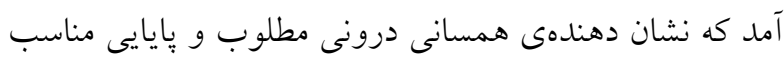

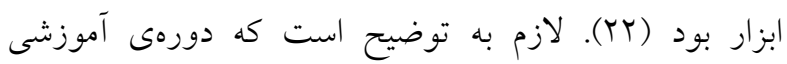



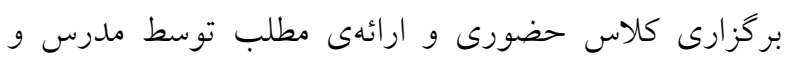



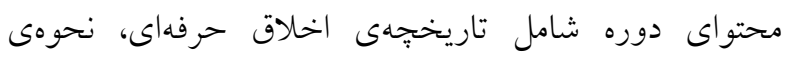

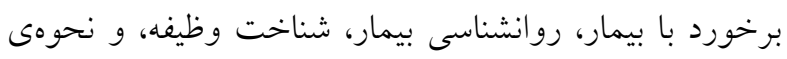

جدول ا: مقايسه نكرش و عملكرد برستاران مورد مطالعه بر حسب شركت در دورههاى آموزش ضمن خدمت اخلاق حرفهاى

\begin{tabular}{|c|c|c|c|c|c|c|c|}
\hline \multirow[t]{3}{*}{ Pvalue } & \multicolumn{2}{|r|}{ عملكرد } & \multirow[t]{3}{*}{ Pvalue } & \multicolumn{2}{|r|}{ نغرش } & ستاران & نغخرش و عد \\
\hline & انحراف & ميانگين & & انحر اف & ميانخين & & \\
\hline & معيار & & & معيار & & & \\
\hline \multirow{3}{*}{$\cdot, 9$} & $\cdot, 01$ & $r, 07$ & \multirow{3}{*}{$\cdot, \mathfrak{\varepsilon}$} & س & r,£o & بله & \multirow{3}{*}{ شر كت در كار كاه } \\
\hline & $\cdot, \mathrm{OV}$ & r,07 & & • & T,EY & خير & \\
\hline & $\cdot, \mathrm{OV}$ & $r, 07$ & & $\cdot, r \varepsilon$ & $r, \varepsilon r$ & كل & \\
\hline
\end{tabular}


جدول ץ: مقايسه نخرش و عملكرد برستاران شركت كننده در دورههاى بازآموزى اخلاق حرفهاى براساس برخى متغيرهاى زمينهاى

\begin{tabular}{|c|c|c|c|c|c|c|c|}
\hline \multirow[t]{3}{*}{ pvalue } & \multicolumn{2}{|c|}{ 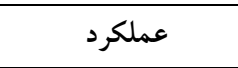 } & \multirow[t]{3}{*}{ pvalue } & \multicolumn{2}{|c|}{ 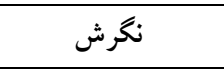 } & \multicolumn{2}{|c|}{ إنخرش و عملكرد يرستاران } \\
\hline & انحر اف & ميانخين & & انحراف & ميانگين & & \\
\hline & كي" & & & - & & & هاي زمينهاي \\
\hline \multirow{3}{*}{$\cdot / V$} & .109 & $T / 00$ & \multirow{3}{*}{$.1 \cdot 9$} & $\cdot / \pi 7$ & $r / \varepsilon q$ & موسوى & \multirow{3}{*}{ 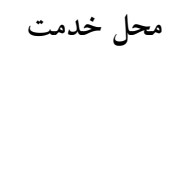 } \\
\hline & $\cdot / \varepsilon 7$ & $T / 71$ & & $\cdot / 7 q$ & $r / r V$ & ولى عصر & \\
\hline & $\cdot / \mathrm{VV}$ & $\Gamma / 乏 \wedge$ & & .10 & $r / \mu$ & بهشتى بـ & \\
\hline \multirow{3}{*}{$\cdot / V$} & $\cdot 10 \varepsilon$ & $r / 7 \varepsilon$ & \multirow{3}{*}{$\cdot / V$} & $\cdot / \mu \varepsilon$ & $r / \varepsilon \varepsilon$ & كمتر از ·اسال & \multirow{3}{*}{ سابقهى خدمت } \\
\hline & .109 & T/OT & & ת ז & $r / 27$ & بين •1-· سال & \\
\hline & $\cdot / 7 r$ & $T / 乏 \wedge$ & & $\cdot / T \Lambda$ & $r / \Sigma)$ & بيش از •r سال & \\
\hline \multirow{3}{*}{$\cdot / \mu$} & $\cdot / 0 \mathrm{~V}$ & $r / 00$ & \multirow{3}{*}{$\cdot / 7$} & . & $T / \varepsilon \varepsilon$ & زن & \multirow{3}{*}{ جنسيت } \\
\hline & & & & & & & \\
\hline &.$/ 79$ & r/ r & & & $T / \Sigma V$ & مرد & \\
\hline \multirow{3}{*}{$\cdot / 1$} & .100 & $T / T V$ & \multirow{3}{*}{$\cdot 10$} & $\cdot \pi \wedge$ & $r / \varepsilon$. & كمتر از •r & \multirow{3}{*}{ سن } \\
\hline & .100 & $r / 0 \Lambda$ & & $\cdot \pi$ & $T / 20$ & بين آ-" & \\
\hline & • & $T /\{7$ & & $\cdot \pi t$ & $T / \Sigma V$ & بالاى •ع سال & \\
\hline \multirow[b]{2}{*}{$\cdot / 7$} & $\cdot / 7$ & T/OT & \multirow[b]{2}{*}{$\cdot / r$} & $\cdot \pi t$ & T/O. & ثابت & \multirow[t]{2}{*}{ شيفت } \\
\hline & $\cdot 10 \mathrm{~V}$ & T/OV & & ( & $r / \varepsilon r$ & در كردش & \\
\hline \multirow{3}{*}{$\cdot / \varepsilon$} & $\cdot 10 \mathrm{~V}$ & T/OV & \multirow{3}{*}{$\cdot / \cdot V$} & ( & $r / \varepsilon \varepsilon$ & يرستار & \multirow[t]{3}{*}{ سمت } \\
\hline & .100 & $r / 70$ & & $\cdot \mu$ & T/O. & سرير ستار & \\
\hline & .101 & $r / Y T$ & & $\cdot / \pi 7$ & $T / 01$ & سوير وايزر & \\
\hline \multirow[b]{2}{*}{$\cdot / r$} & .109 & Y/OV & \multirow{2}{*}{$\cdot / \cdot \wedge$} & • Mr & $r / \varepsilon \varepsilon$ & ل ل ليسانس & \multirow[t]{2}{*}{ ميزان تحصيلات } \\
\hline & $\cdot / \varepsilon \varepsilon$ & $0 / 2 Y$ & & $\cdot \pi \varepsilon$ & T/ON & فوق ليسانس & \\
\hline
\end{tabular}

خدمت، جنسيت، سن، شيفت كارى و سمت ارتباط معنادارى

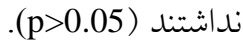

بحث

براساس نتايج بدست آمده، ميانخين نمرهى نخرش و وكاث

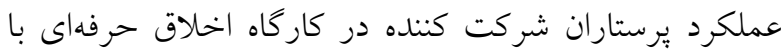
برستارانى كه شركت نداشتند تقريبا يكسان بود. لذا جنين

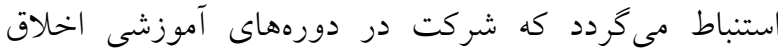
حرفهاى نتوانسته است در نخرش و عملكرد يرستاران تفاوت
براساس نتايج نشان داده شده در جدول ل، ميانخين نمرهى يرستاران شركت كننده در كاركاه اخلاق حرفهاى يرستاران با بان افرادى كه شركت نداشتند تقريبا يكسان بود. با توجه به جدول r كه نتايج سنجش نغرش و عملكرد شركت كنند كان در دورهى آموزشى را بر اساس برخى متغيرهاى زمينهاى

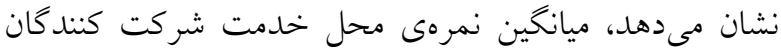
در بيمارستان موسوى بالاتر از بيمارستانهاى ولى عصر و

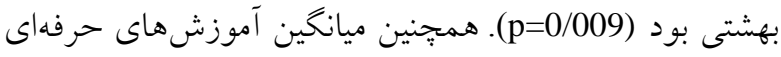
يرستارى از نظر ساير متغيرهاى زمينهاى از قبيل سابقهى 
قدرت قضاوت اخلاقى دانشجويان برستارى است (11). حال

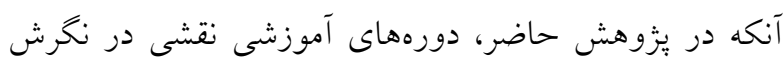
يرستاران نسبت به اخلاق حرفهاى نداشت و همسو با بروسي يُزوهشهاى ذكر شده نبود. ميانخين آموزشهاى حرفهاى بهري يرستارى از نظر سابقهى خدمت، جنسيت، سن و شيفت كارى ارتباط معنادارى نداشتند. در مطالعهى عضدى و و ديخران نيز بين عوامل جمعيت شناختى، ميزان آكاهى در مورد كدهاى اخلاقى و ميزان بروز خطا ارتباط آمارى معنى دارى وجود نداشت ( (1). در حالى كه مطالعه Yoder نشان داد كه متغيرهاى سن، بيش زمينهى كارى و تجربهى كارى رابطه معنى دارى

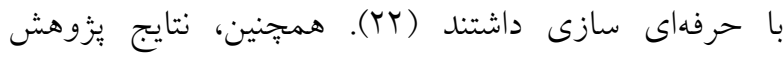
دهقانى و ديخران نيز برخلاف اين بيزوهش كه شيفتهاى

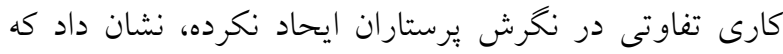

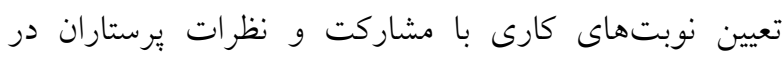

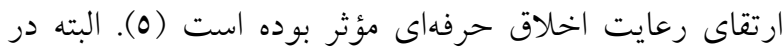

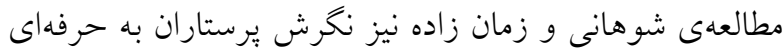

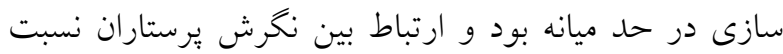

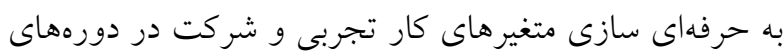

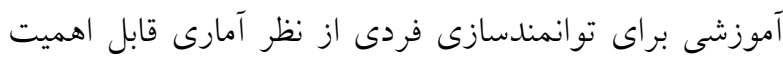

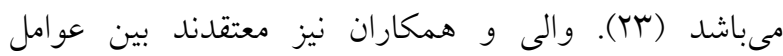
سازمانى و حرفهاى و جنسيت و نيز بين عوامل برنامه ريزى

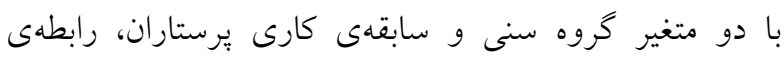

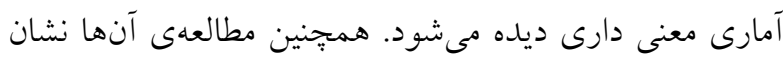
داد توجه به عوامل حرفهاى از اهميت بسيار زيادى در برنامه

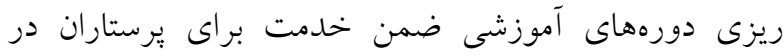
مراكز بيمارستانى برخوردار بوده و بايد مورد توجه خاص قرار گيرد. در مطالعهى حاضر، محل خدمت از نظر نخرش به اخلاق حرفهاى معنى دار بود. بطورىكه نخرش يرستاران به اخلاق

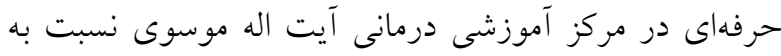
دو مركز ديخر بالاتر بود. كه دليل آنرا مىتوان احتمالاً به درنه
ايجاد كند. با توجه به اينكه محتواى اين كاركاهها براى


كنندگان به اخلاق حرفهاى برنامه ريزى شده بود، يزوهش حاضر تا حدودى با نتايج يزوهش كلاته ساداتى و ديخران

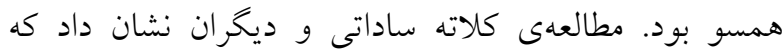

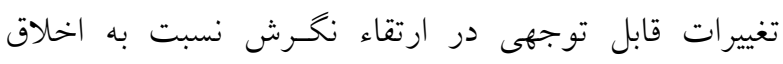

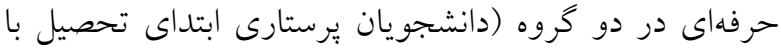

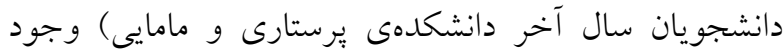
نداشت به طورى كه نحرش در كروه يايان تحصيل كاهش

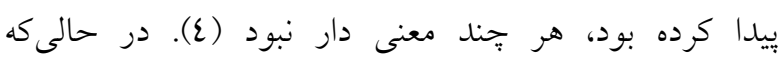

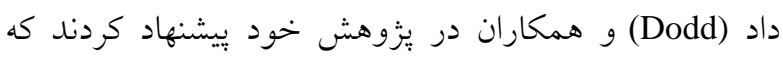
براى افزايش قدرت يرستاران در تيم سلامت، بايد به آموزش اخلاق حرفهاى بلعنوان يك ضرورت توجه بيشترى كرد. از نظر آنها لازمههاى صحيح نقشهاى برسئ برسئارى علاوه بر انجام

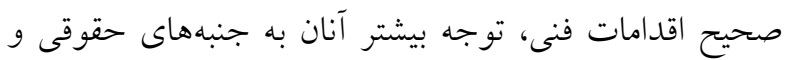

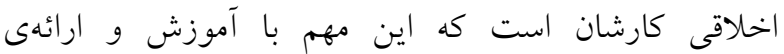
راهبردهاى مناسب براى عملكرد اخلاقى يُرستاران قابل دستيابى و توسعه است (·r). كراندتين در مطالعهاى كه انجام

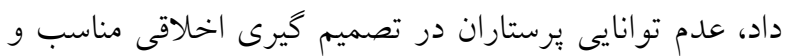

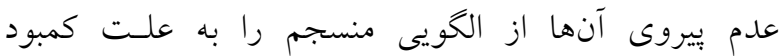

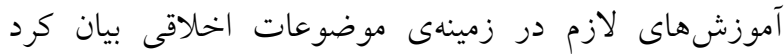

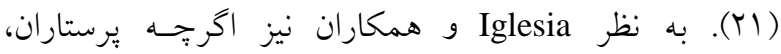

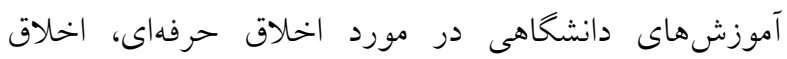
زيستى و قوانين برستارى را كذراندهاند، ولى به آموزشهاى هورد مستمر دورهاى نيز نياز دارند (7).Wehrwein معتقد است كه آموزش اخلاق حرفهاى در ارتقاء آكاهى دانشجويان از موضوعات اخلاقى و كاربرد آنها در محيط كار موثر است. علاوه بر اين، توانايى تصميم گيرى اخلاقى در دانشجويانى كه درس اخلاق را گذرانده بودند، بيشتر از دانشجويانى بود كه اين درس را نخذرانده بودند. يافتهاى اين يُزوهش گَّاه

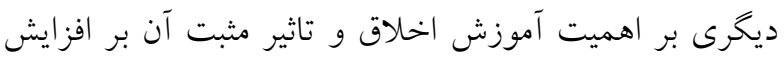




$$
\begin{aligned}
& \text { و اجرا شود. به نظر مىرسد در مورد علل عدم تاثير مناسب }
\end{aligned}
$$

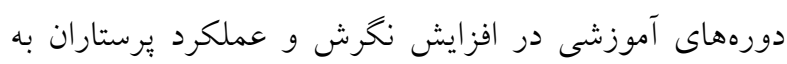

$$
\begin{aligned}
& \text { مباحث اخلاق حرفهاى، بايد مطالعات بيشترى انجام شود. }
\end{aligned}
$$

\section{تقدير و تشكر}

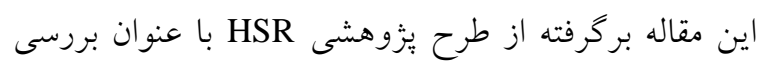

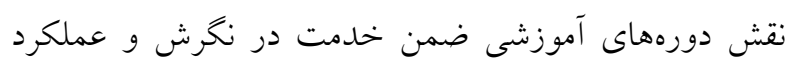

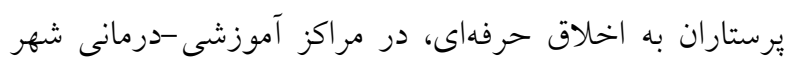

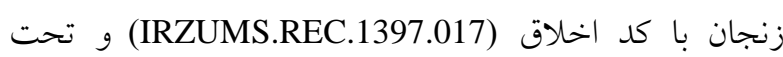

حمايت مالى دانشخاه علوم يزشكى زنجان بان انجام كرفته است.

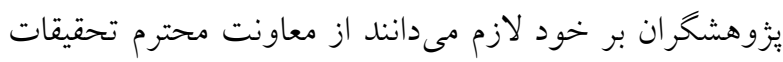

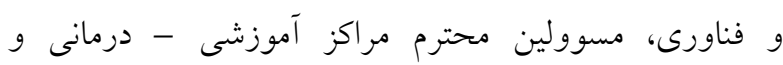

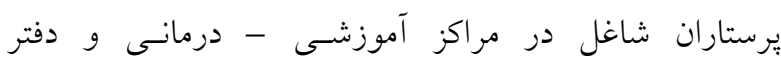

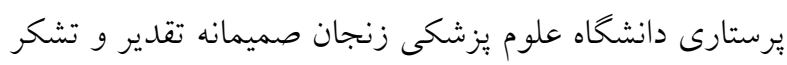

نمايند.

\section{References}

1- Azodi P, Vahedparast H, Nowroozi L, Khalili A, Shamsizadeh M, Mirzaei M.S, Jahanpour F. A Survey of the Relationship between Knowledge of Ethics Codes and the Rate of Nursing Errors Reported by Nursing Personnel Employed in Bushehr Hospitals in 2014, Journal of Nursing and Midwifery Hamedan, 2016; 24(2): 113-119.

2- Khaki S, Esmail Pourzanjani S, Mashouf S. The Study of the Relationship Between Nursing Professional Ethics and Quality of Providing Care from Patients' Viewpoint. Nursing and Midwifery Clinical Journal, 2016; 5(1): 1-11.

3- Karam Pourian A, Imeni B, Torkzaban P. A survey on the Attitude towards Professional Ethics in the Faculty Members of Hamedan Dental School in 2012, research in dental sciences,2013; 10(1): (serial No. 35), 43-51.

4- Kalateh Sadaty A, Salehzadeh, H, Hemmati, S, Darvish, M, Ilvan Kashkouee R. Comparison of

$$
\begin{aligned}
& \text { انسجام بيشتر در نحوهى برگزارى دورههاى آموزشى در آن } \\
& \text { مركز آموزشى - درمانى ذكر كرد. }
\end{aligned}
$$

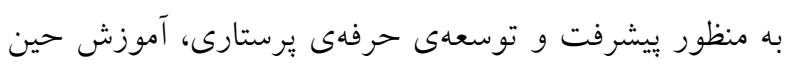

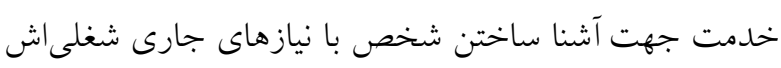

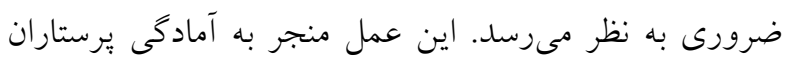

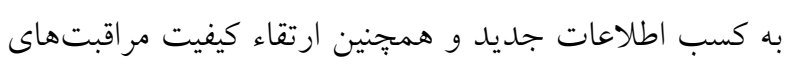



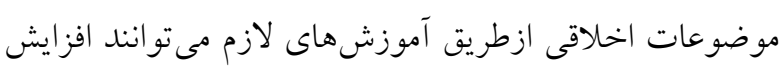

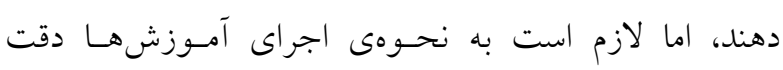

$$
\begin{aligned}
& \text { بيشترى شود. } \\
& \text { نتيجه كَيرى } \\
& \text { با توجه به نتايج مطالعهى حاضر، ل لازم است به نحوهى }
\end{aligned}
$$

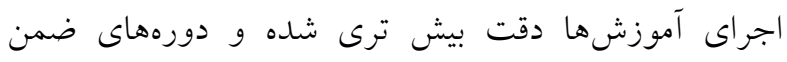

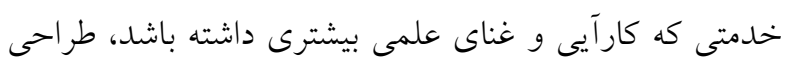

Attitude of Nursing Students at the Beginning of Education with Last Year Students of Hazrat Fatemeh Shiraz Nursing and Midwifery Faculty on Professional Ethics (2012), Quarterly Journal of Education and Ethics in Nursing, 2013; 2(3): $34-40$.

5- Dehghani A, Mohammad Khan Kermanshahi S. The Level of Observance of Professional Ethics Criteria in Nursing Performance from the Viewpoint of Nursing Staff of Tehran University of Medical Sciences. New Care, Journal of Nursing and Midwifery Birjand University of Medical Sciences,2012; 9(3): 208-216.

6- Iglesias M.E L, Vallejo R. B. d. B. nurse attitudes in relation to health care ethics and legal regulations for nursing, 2014; 20 (2): 255-264.

7- Gastmans CA. Fundamental Ethical Approach to Nursing: some proposals for ethics education. Nurs Ethics 2002; 9(5): 494-507.

8-Chitty KK, Black BP. Professional nursing 
(text only). 6th ed. Philadelphia: W.B Saunders; 2010 .

9- Dehghani A, Mosalanejad L, Dehghan-Nayeri N. Factors affecting professional ethics in nursing practice in Iran: a qualitative study, 2015; 16:61:1-7.

10- Dehghani A, Dastpak M, Gharib A. Barriers of Observance of Professional Ethics Standards in Clinical Care from Nurses' viewpoints. Iranian Journal of Medical Education, 2013; 13(5):421430 .

11- Borhani F, Alhani F, Mohammadi E, Abbaszadeh A. Development of Nursing Professional Ethics Qualification, Necessities and Challenges in Ethics, Ethics and Medical History,2009;2(3): 27-38.

12- Dehghani A, Daghighi Asli A, Pourvali F. The Effect of In-Service Training on Personnel's Capability and Job Performance in an Insurance Company. Insurance Research, 2015; 30(2): (serial No. 118), 35-60.

13- Monajati S.F, Moradi A, Kheyri B. The Relationship between In-Service Training of Nursing Personnel and Occupational Outcomes: Organizational Commitment, Job Satisfaction and Organizational Citizenship Behavior. Iranian Journal of Medical Education, 2014; 14(6): 495506.

14- SWANSBURG. RC. Nursing Staff Development. A Component of Human Resource Development. 1995; London: Jones \& Bartlett Publishers.

15- Norushe T.F, Rooyen D. V, Strumpher J. Inservice education and training as experienced by registered nurses,2004;27:4:63-72.
16- Fry ST. Teaching ethics in nursing curricula. Traditional and contemporary models. Nurs Clin North Am 1989; 24(2): 485-497.

17- MELL ISH, JM \& BR INK, H. Teaching the practice of nursing. A text in nursing didactics. 3rd edition, 1990; Durban: Butterworth.

18- Ahmadi F. Evolution Factors Impact on Professional Ethics in Service Organization. Ethics in science and Technology. 2013; 8 (3).

19- Nouhi S, Ghana S, Jouybari L, Kalantari S. Evaluating attitudes and performance of nursing students, teachers, managers towards ethics in nursing profession. J Educ Ethics Nurs. 2017; 5 (2):1-7 [URL: http://ethic.jums.ac.ir/article-1-373fa.htm].

20- Dodd SJ, Johnson BS, Brown- Saltzman K, shirk $M$, Wunch $K$. Expanding nurses participation in ethics: an empirical examination of ethical assertiveness. Nurs Ethics 2004; 11(1): $15-27$.

21- Grundstein-Amado R. Ethical decision making processes used by health care providers, $\mathrm{J}$ Adv Nurse.1993; 18(11): 1701 - 9 .

22- Yoder LH. Staff nurses' career development relationships and self-reports of professionalism, job satisfaction, and intent to stay. Nurs Res 1995; 44 (5): 290-7.

23- Shohani M, Zamanzadeh V. Nurses' Attitude towards Professionalization and Factors Influencing It, 2017; 6(4), 345-357. 